\title{
Distribution and population size of Cheddar hawkweed Hieracium stenolepiforme (Asteraceae)
}

\author{
Helena J. Crouch*, Elizabeth J. McDonnell, Stephanie Miles, Timothy C.G. Rich
}

*Corresponding author: Helena J. Crouch, email: helenacrouch@sky.com

This pdf constitutes the Version of Record published on $11^{\text {th }}$ February 2019

\begin{abstract}
The distribution and population size of Hieracium stenolepiforme (Pugsley) P. D. Sell \& C. West, Cheddar hawkweed (Asteraceae) has been assessed. It is endemic to Cheddar Gorge and the adjacent Black Rock Nature Reserve, Somerset, England (v.c. 6 North Somerset). Historical records show that it has been recorded in Cheddar Gorge and at Black Rock but has declined. On 11 June 2000, 52 plants were counted in the main gorge and 5 plants at Black Rock; on 14 June 2016, 59 plants were recorded in Cheddar Gorge but none at Black Rock. Hieracium stenolepiforme is IUCN (2001) threat status 'Critically Endangered'.
\end{abstract}

Keywords: endemic; threat status; Cheddar Gorge; Black Rock; Somerset.

\section{Introduction}

Cheddar hawkweed Hieracium stenolepiforme (Pugsley) P.D. Sell \& C. West is a rare English endemic confined to Cheddar Gorge (v.c. 6 North Somerset). There is already concern that the rare hawkweeds have declined in Cheddar Gorge (FitzGerald \& McDonnell, 1997), and indeed Rich et al. (2008) noted a marked reduction in $H$. cyathis (Ley) W. R. Linton. As there has been little information collected on the rare endemic $H$. stenolepiforme, the aim of this paper is to assess its current status.

Hieracium stenolepiforme was first collected at Cheddar in 1839 by C.C. Babington (specimen in CGE). It was originally included in the Scandinavian $H$. stenolepis until it was described at varietal level by Pugsley (1948) as Hieracium britannicum F.J. Hanbury var. stenolepiforme Pugsley, and subsequently raised to species status by Sell \& West (1955). Pugsley (1948) also cited material from Rhaeadr Fawr (v.c. 47 Montgomeryshire) under his new variety; this material is now treated as $\mathrm{H}$. stenopholidium (Dahlst.) Omang. Other records in databases from outside Cheddar probably result from errors in synonymy.

Sell \& Murrell (2006) include H. stenolepiforme in Section Stelligera Zahn, and it forms part of the $H$. britannicum group, and $H$. britannicum may be the species from which it is derived (Sell \& West, 1968). It is characterised by the somewhat glaucous rosette leaves often red-flushed below, which are usually glabrous above (a few hairs may be present near the margins) and oblong to lanceolate with acute teeth at the base, the 0-1 stem leaf, and the acute, 6-12 mm long, narrow (0.5-1.5 $\mathrm{mm}$ ) involucral bracts with numerous simple hairs, numerous short glandular hairs and few stellate hairs, and the yellow styles (Figs. 1 and 2). Two similar species also grow at Cheddar: H. cyathis has more or less entire leaves which are often blotched 
and a very short acladium, and $H$. schmidtii has entire leaves with numerous long hairs on the upper surface.

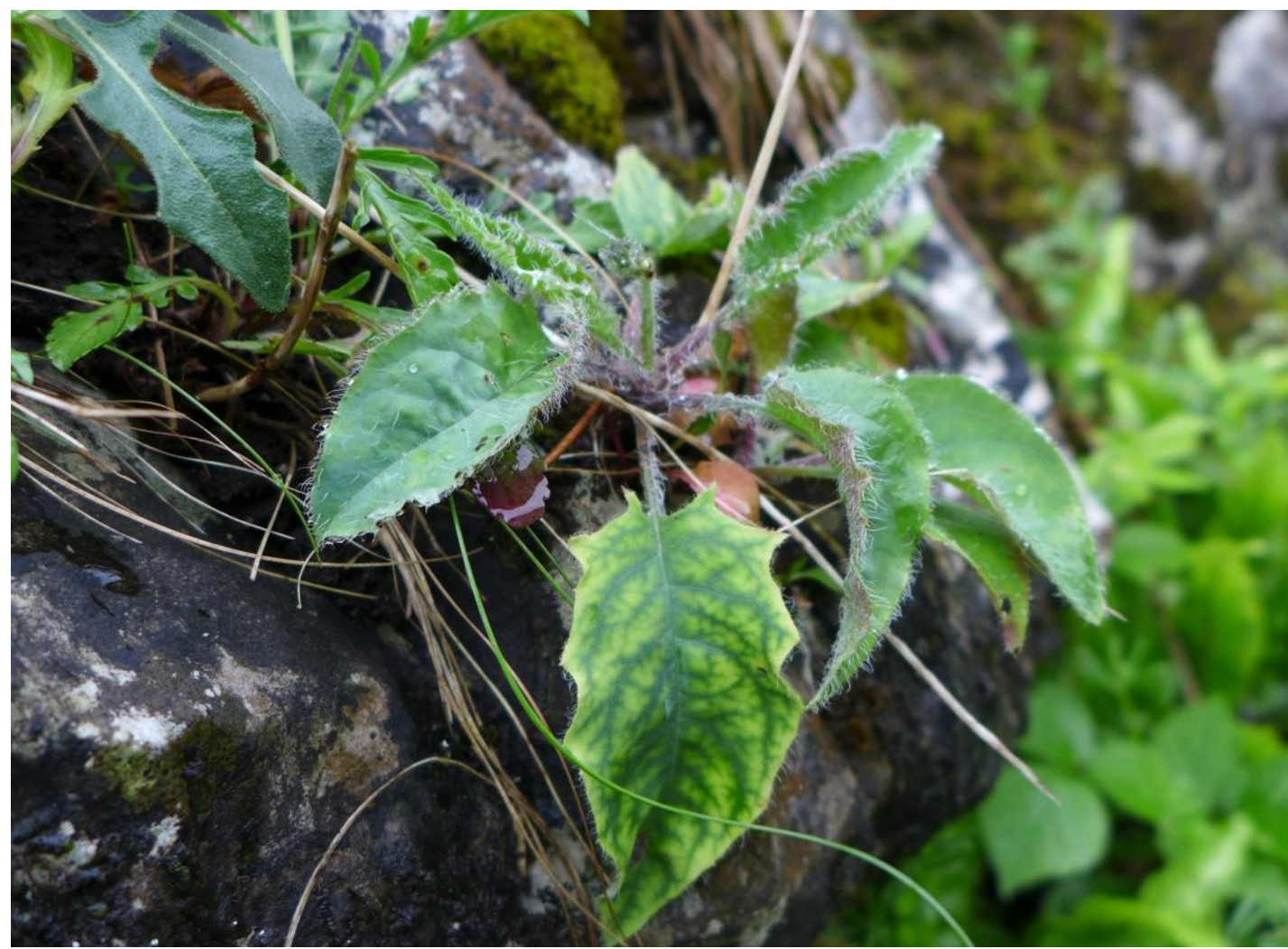

Figure 1. Rosette of $\boldsymbol{H}$. stenolepiforme at Cheddar in 2016.

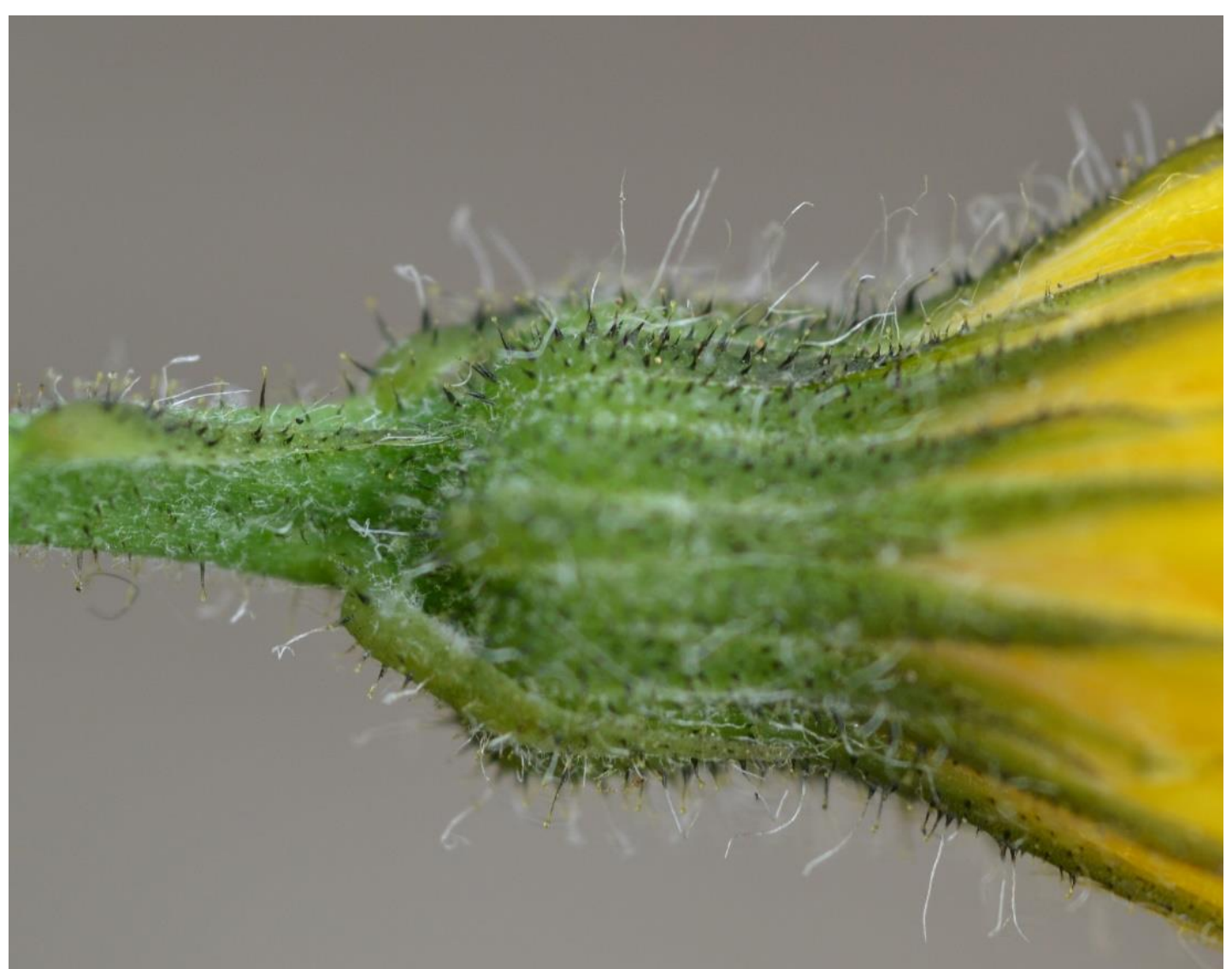

Figure 2. Close-up of involucral bracts showing numerous long simple white hairs, numerous glandular hairs and very few stellate hairs. 


\section{Historical records}

There are sporadic records of $H$. stenolepiforme since 1839, mostly based on herbarium material (material examined in BM, NMW and CGE). Most records refer to the main gorge and some include information on its frequency. Murray (1896) cited it as "Very fine, but not plentiful, on the steep slopes under cliffs in the gorge of Cheddar, preferring a north aspect; E. F. Linton". Ley (1906) noted 'This [H. cyathis] and $H$. lima [now included in $H$. schmidtii Tausch.] are decidedly the most abundant hawkweeds of Cheddar; $H$. stenolepis [i.e. $H$. stenolepiforme] and $H$. schmidtii being less common'. White (1912) recorded it as 'now scarce' in the gorge. Marshall recorded it as scarce on rocks in 1914 (NMW). H.W. Pugsley collected it in 1946 (BM), and P.D. Sell collected it in 1952 and again in 1969 (CGE), the last time it was recorded from the main gorge. It was not refound in the gorge by the BSBI Hieracium study group in May 1983 (Bevan, 1985), and FitzGerald \& McDonnell (1997) did not find any in the main gorge.

In 1985, 100 plants were found on ledges of the disused quarry at Black Rock (FitzGerald, 1986), thought to be the unconfirmed 'Long Wood' locality of White (1912). FitzGerald \& McDonnell (1997) reported four flowering plants on the vertical cliffs at Black Rock quarry and two or more immature plants on low grassy ledges a few metres to the north, below the wooded NE-facing cliffs. Green et al. (1997) reported it in small quantity from a rock face at Black Rock. It was last recorded at Black Rock in 2003 by S.J. Parker and has not been seen since despite several searches.

\section{Population estimates}

Two recent surveys have been carried out by walking along the gorge and checking accessible plants visually or with binoculars. It was not always possible to be certain of the identification of plants located on high rocks with binoculars, and nonflowering plants were very hard to see.

The first population estimate was carried out by EJM and TCGR on 11 June 2000 when 52 plants were counted in the main gorge between Bone Hole and the covered reservoirs, and five plants at Black Rock (NMW; Rich \& McDonnell, 2001).

A second detailed survey of the gorge and adjacent areas was carried out by HJC and TCGR on 14 June 2016 when 58 flowering plants and 1 immature plant were found between Sow's Hole and the Horseshoe Bend (much the same areas as in 2000; K), but none were found at Black Rock (Figs. 3 and 4). The population in the main gorge appears relatively stable over the 16 year period but it has gone from Black Rock.

Given the difficulty of searching the vast cliffs successfully without rope access, these population counts are no doubt underestimates but are the best information available. We were unable to see any H. stenolepiforme on 27 May 2016 before they flowered, and recommend future surveys should be carried out in early June at peak flowering time. 


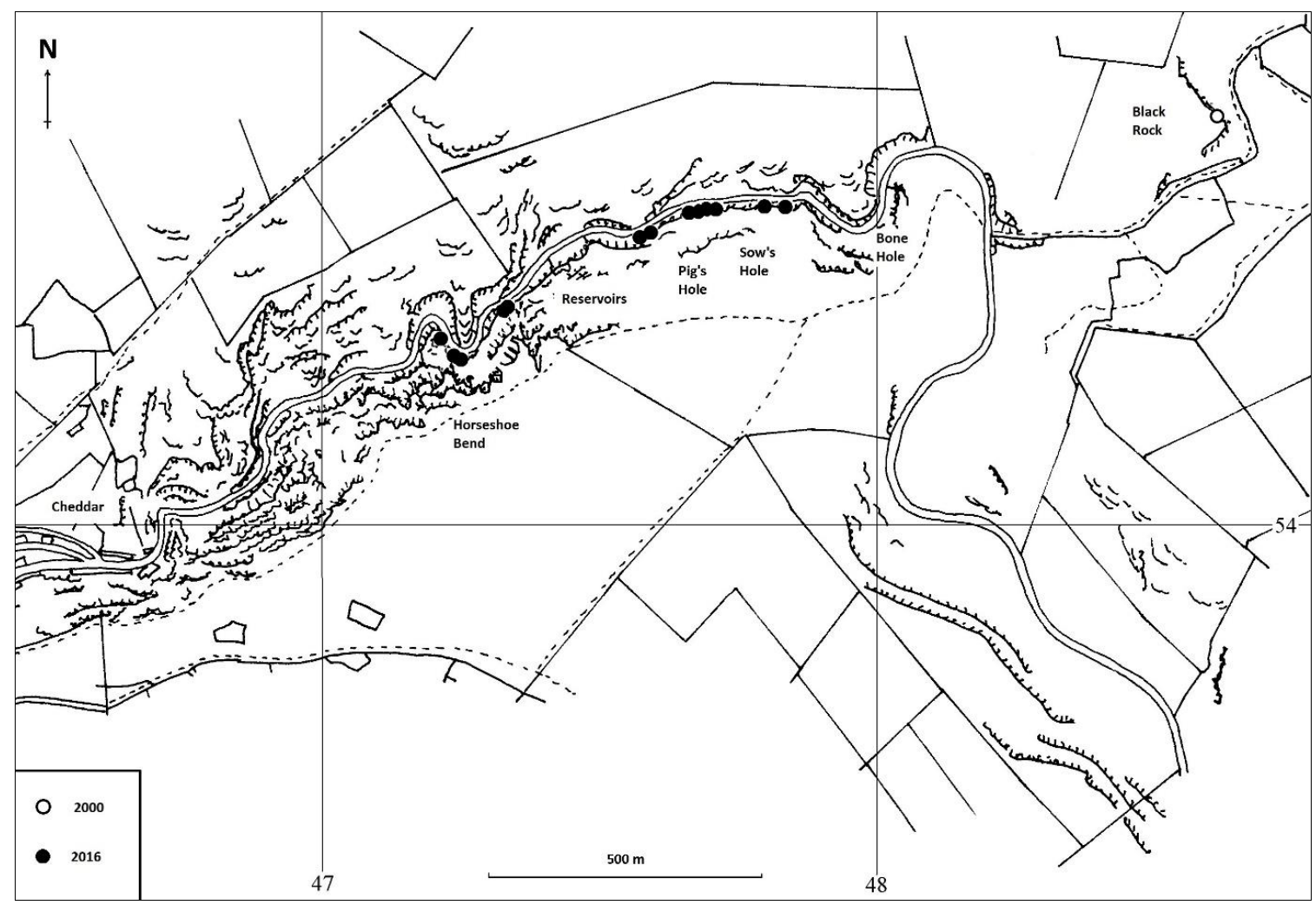

Figure 3. Distribution of $\boldsymbol{H}$. stenolepiforme at Cheddar in 2016.

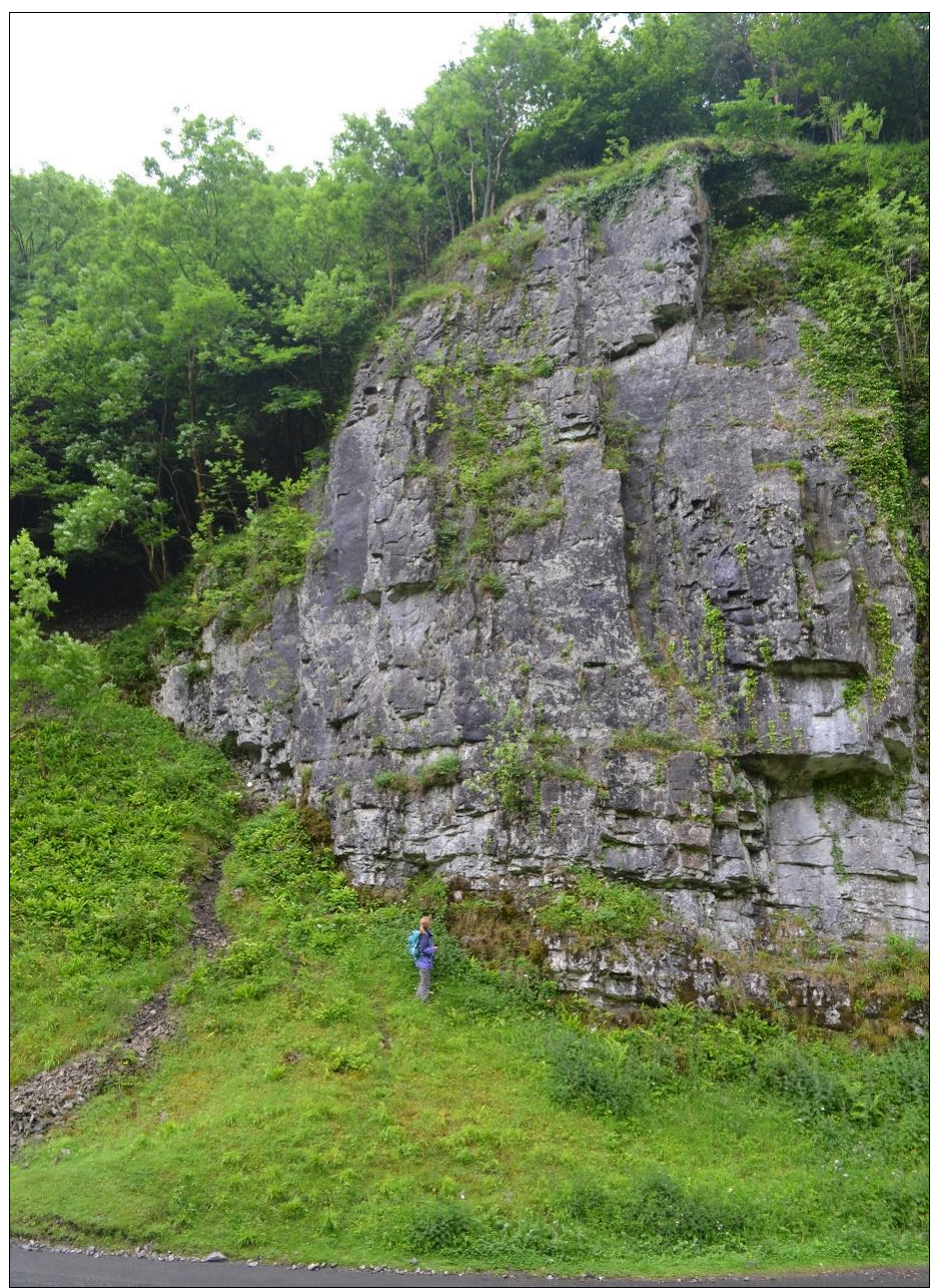

Figure 4. Hieracium stenolepiforme location on cliff near Pig's Hole, 2016. 


\section{Discussion}

In contrast to the observations of Ley (1906), the commonest hawkweed in Cheddar Gorge in 2016 was $H$. argillaceum (H. acuminatum sensu lato) with $H$.

stenolepiforme scarce. During these and subsequent surveys in 2016 we found only 15 plants of $H$. cyathis, 12 plants of $H$. schmidtii and 8 plants of the other Cheddar speciality H. angustisquamum (Pugsley) Pugsley within the gorge (Crouch, 2016). This confirms that the rarer Cheddar hawkweeds have declined.

We agree with FitzGerald (1986) that it is difficult to know whether $H$. stenolepiforme has always been scarce in the main gorge or whether it has become more so recently. Historically it was collected regularly until the 1960 s, so was presumably more frequent then. Hawkweeds may have spread from rocks into grassland after the post-war decline in grazing, and following the reintroduction of goats and sheep are now declining again in areas accessible to sheep and goats. However, there is clear evidence for recent loss at Black Rock, probably as a result of shading by the growth of ash trees and scrub and perhaps also following recent rock stabilisation works. The inaccessibility of the remaining locations on cliffs would suggest that it is unlikely to be further affected by sheep and goat grazing in the main gorge, but shading from trees and scrub continues to threaten its survival.

The current population of 59 plants is confined to the steep NW-facing side of the cliffs of Cheddar Gorge alone. The small population size, confined to one site, with a loss from Black Rock means it is IUCN (2001) threat status 'Critically Endangered'. A small amount of seed was collected from the main gorge in 2016 for the Millennium Seed Bank, which was further bulked up from cultivated material in 2017 and 2018.

\section{Acknowledgements}

We would like to thank Bob Corns, Anne Strong, Neil Watson and James Stone. The collection of seed was funded by an Esmée Fairbairn Trust grant to the Millennium Seed Bank.

\section{References}

Bevan, J. 1985. Reports of meetings. Cheddar Gorge, Somerset, v.c.6, Saturday $21^{\text {st }}$ May 1983. BSBI Hieracia Group Notes, 8: 1-2.

Crouch, H.J. 2016. Rare plants survey of the Cheddar Complex SSSI: 2016. Unpublished report to Natural England.

Fitzgerald, R. 1986. New records from v.c. 6, North Somerset. BSBI Hieracia Group Notes, 10: 5-6.

FitzGerald, R. \& McDonnell E.J. 1997. Cheddar Gorge Rare Plant Survey. Unpublished report to English Nature.

Green, P.R., Green, I.P. \& Crouch, G.A. 1997. The atlas flora of Somerset. Crewkerne: Privately published.

IUCN 2001. IUCN Red list categories and criteria. Version 3.1. Gland: IUCN.

Ley, A. 1906. H. cyathis, Ley. Report of the Botanical Exchange Club of the British Isles, 2: 175.

Murray, R.P (1896). The flora of Somerset. Taunton: Barnicott \& Pearce.

Pugsley, H.W. 1948. A prodromus of the British Hieracia. Journal of the Linnean Society of London (Botany), 54: 1-356. 
Rich T.C.G. \& McDonnell, E.J. 2001. Distribution and conservation of Hieracium cyathis, Chalice Hawkweed. Unpublished report from National Museum of Wales to Countryside Council for Wales and English Nature.

Rich, T.C.G., McDonnell, E.J. \& Lledó, M.D. 2008. Conservation of Britain's biodiversity: the case of Hieracium cyathis and its relationship to other apomictic taxa. Botanical Journal of the Linnean Society, 156: 669-680.

Sell, P.D. \& Murrell, G. 2006. Flora of Great Britain and Ireland. Volume 4. Cambridge: Cambridge University Press.

Sell, P.D. \& West, C. 1955. Notes on British Hieracia I. Watsonia, 3: 233-236.

Sell, P.D. \& West, C. 1968. Hieracium L. In, Perring, F.H. ed., Critical Supplement to the Atlas of the British flora. London: BSBI.

White, J.W. 1912. The flora of Bristol. Bristol: John Wright \& Sons.

Copyright retained by author(s). Published by BSBI under the terms of the Creative Commons Attribution 4.0 International Public License 